\title{
Hydrographic and navigational analysis of Lower Oder shipping conditions - case study of the backflow occurrence
}

\author{
Piotr Medyna ${ }^{1, *}$, and Paulina Sobkowicz ${ }^{2}$ \\ ${ }^{1}$ Instytut Nawigacji Morskiej, Akademia Morska w Szczecinie, Wały Chrobrego 1-2, 70-500 \\ Szczecin, Polska \\ ${ }^{2}$ Centrum Naukowo - Badawcze Analizy Ryzyka Eksploatacji Statków, Akademia Morska \\ w Szczecinie, Wały Chrobrego 1-2, 70-500 Szczecin, Polska
}

\begin{abstract}
One of the significant limitations of inland waterway transport on the Oder River is the water level. Its variability determines the minimum clearance under the bridges and thus the maximum drought of moving vessels. An important factor affecting the water level in the Oder River is the phenomenon of wind backwater. Certain pressure field distribution situations may affect in an increase of water level on the coast and thereby block the outflow of river waters. In this paper an example of the limitations of inland navigation in the estuarine part of the Lower Oder under the weather conditions on the southern Baltic Sea in autumn 2016 is presented. For the analysis area of Szczecin Waterway Node and section of Oder River from Szczecin to Gryfino was chosen. Based on data the weather and navigational conditions of the area of the Lower Oder were assessed. Occurring winds, currents and changes in water level has been analyzed. In the situations of unfavorable raise of the water level in the river, inland navigation is redirected to the section of Regalica River, and a section of the port of Szczecin region is closed. This causes obvious difficulties and results in prolonged ships routes. Additional obstacle that take place here is an arbitrarily determined time of railway bridge span lifting in Szczecin Podjuchy.
\end{abstract}

\section{Introduction}

Sailing conditions on the inland waterways are determined by navigational and hydrometeorological factors. The navigational factors include, among others parameters of inland waterways, state of buoyage and navigational infrastructure.

The group of hydro-meteorological factors include the impact of winds and currents, ice phenomena, high-water stage and low-water stage. The water level in the river determines the transit depth and the minimum clearances under bridges and thus the transport capacities of inland vessels in the area.

In the case of conditions of exceeding the highest navigable water, navigation on the section marked out by water gauges indicating exceeding is closed.

\footnotetext{
*Corresponding author: p.medyna@am.szczecin.pl
} 
The impact of factors mentioned above varies depending on the location of the river section in the river basin. A special phenomenon affecting only a mouth section of the river is the phenomenon of backwater caused by storm surges, which can be seen on the waters of the Lower Oder.

\section{Hydrographic and navigational analysis of Lower Oder}

Oder River at km 704.1 divides into Western Oder and Eastern Oder. In the region of the river division on the Western Oder there is located valvular weir that prevents shipping directly from the Oder River to Western Oder. On the $3.0 \mathrm{~km}$ of Western Oder counting from this weir, HFM Canal debouches to the Oder. Canal since Hohensaaten, runs laterally in relation to the Oder. Western Oder is the original riverbed.

Western Oder has a total length of 36.55 kilometers counting from the weir in Widuchowa to the bridge on the Castle Route (Trasa Zamkowa) in Szczecin. Western Oder is divided into three main sections:

- Western Oder: km 0,0 - km 3,0 (HFW Canal)

- Western Oder: km 3,0 - km 17,15 (end of frontier section)

- Western Oder: km 17,15 - km 36,55 (Szczecin, Castle Route (Trasa Zamkowa) bridge.

Council of Ministers of 07 . May 2002 regulation on the classification of waterways defines the parameters required for shipping lanes, together with the assignment to the class [1]. Western Oder has the class Vb. Tab. 1 shows the operating parameters for the river holding class $\mathrm{Vb}$.

Table 1. Operating parameters of inland waterway with the Vb class [1].

\begin{tabular}{|c|c|}
\hline Parameter & Value \\
\hline Minimum dimensions of the shipping lane \\
\hline Width of the shipping lane & $50.0 \mathrm{~m}$ \\
\hline Transit depth & $2.8 \mathrm{~m}$ \\
\hline Minimum dimensions of the canal \\
\hline Radius of the arc of axis of the shipping lane & $800.0 \mathrm{~m}$ \\
\hline Width of the waterway & $45.0 \mathrm{~m}$ \\
\hline Smallest water depth in the canal & $3.5 \mathrm{~m}$ \\
\hline Madius of the arc of axis of the shipping lane & $800.0 \mathrm{~m}$ \\
\hline Minimum dimensions of the locks \\
\hline Length of the lock & $12.0 \mathrm{~m}$ \\
\hline Depth at the low threshold & $187.0 \mathrm{~m}$ \\
\hline
\end{tabular}

The width of Western Oder shipping lane is primarily limited by bridges. There is

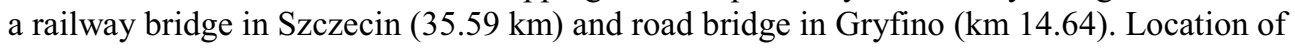
the bridge spans reduces the accessibility of the shipping lane.

In the case of the railway bridge in Szczecin width of the shipping lane at the right and left bridge span is $10.0 \mathrm{~m}$, while the entire width of the span arch of road bridge in Szczecin the width is only $17.5 \mathrm{~m}$. Under the road bridge in Gryfino navigable route is limited to a width of $30 \mathrm{~m}$ [9].

The problem is also the minimum clearances under bridges. For the class $\mathrm{Vb}$ waterway minimum clearance (above the highest navigable water) should be $5.25 \mathrm{~m}$.

Currently, the vertical clearance under the road bridge in Szczecin at the lowest point of arc span is a total of width of $3.40 \mathrm{~m}$. Under the railway bridge in Szczecin, this value is $3.79 \mathrm{~m}$. 
Transit depth is determined based on measuring the water level and announced daily in shipping information. Therefore this parameter is variable and depends on the part of the river:

- Western Oder: km 0.0 - km 3.0 - transit depth variable

- Western Oder: km 3.0 - km 17.15 - transit depth variable

- Western Oder: km 17.15 - km 36.55 - transit depth constant

Information of transit depth can be obtained from web site, using Transit Depth Calculator. An example is shown in Table 2.

Table 2. Transit depth calculator of RZGW (Regional Water Management) [6].

\begin{tabular}{|c|c|c|c|c|c|c|c|}
\hline \multirow{2}{*}{$\begin{array}{c}\text { Section of } \\
\text { the Oder } \\
\text { river }\end{array}$} & $\mathrm{km}$ & Water gauges & \multicolumn{2}{|c|}{ The current measurement } & \multicolumn{2}{c|}{ Current state } \\
\cline { 5 - 8 } & & $\begin{array}{c}\text { Measurement } \\
\text { date }\end{array}$ & $\begin{array}{c}\text { Water } \\
\text { level }\end{array}$ & $\begin{array}{c}\text { the } \\
\text { transit } \\
\text { depth }\end{array}$ & $\begin{array}{c}\text { enter the } \\
\text { water } \\
\text { level }\end{array}$ & $\begin{array}{c}\text { the } \\
\text { transit } \\
\text { depth }\end{array}$ \\
\hline $\begin{array}{c}\text { Western } \\
\text { Oder }\end{array}$ & $\begin{array}{c}\mathrm{km} 0,0 \\
-0,3\end{array}$ & $\begin{array}{c}\text { Gryfino O.Z } \\
\text { (Water gauges } \\
\text { in Mescherin })\end{array}$ & 19.12 .2016 & 529 & 212 & & \\
\hline $\begin{array}{c}\text { Western } \\
\text { Oder }\end{array}$ & $\begin{array}{c}\mathrm{km} 0,3 \\
-17,1\end{array}$ & $\begin{array}{c}\text { Gryfino O.Z } \\
\text { (Water gauges } \\
\text { in Mescherin })\end{array}$ & 19.12 .2016 & 529 & 401 & & \\
\hline
\end{tabular}

Current water level is measured by water gauges. On the waters of Western Oder there are two water gauges administered by Poland: Gryfino (km 14.4) and Szczecin $(35.95 \mathrm{~km})$ and two stream gauges administered by Germany: Gartz $(8.06 \mathrm{~km})$ and Mescherin (km 14.08).

Exceeding the states of highest navigable water (WWŻ) is associated with reduced clearances under bridges, increased waving (especially on the waters of Szczecin Waterway Node - Szczeciński Węzeł Wodny) and restrictions to navigation. One of the limitations occurring on the Oder River is closing for navigation the lower sections of the Western Oder due to reduced clearance under the road/rail bridge over Western Oder.

In such cases, the shipping goes through Regalica River under the railway drawbridge. Railway drawbridge opens at fixed hours that make impossible the smooth flow of inland ships. Tab.3. shows the actual bridge opening hours.

Table 3. Rail drawbridge on the river $733.7 \mathrm{~km}$ opening schedule [9].

\begin{tabular}{|c|c|}
\hline Bridge opening period & $\begin{array}{c}\text { Time of real daily bridge } \\
\text { opening by administrator } \\
\text { (PKP PLK S.A.) }\end{array}$ \\
\hline \multirow{4}{*}{$11.12 .2016-11.03 .2017$} & $08: 20-08: 40$ \\
\cline { 2 - 2 } & $10: 10-10: 30$ \\
\cline { 2 - 2 } & $12: 20-12: 40$ \\
\cline { 2 - 2 } & $13: 56-14: 16$ \\
\cline { 2 - 2 } & $16: 05-16: 25$ \\
\hline
\end{tabular}




\section{An example of weather situation causing backwater and rising water levels in the estuary part of Oder River}

Fig.1. shows the situation of rapidly changing pressure field distribution over Europe, which consequently caused a short-term storm surge, backwater on the Oder and exceeding alarm levels on the river. Storm surge is understood here as a sudden rise of water level in coast area caused by passing low-pressure system, which would not occur without the accompanying strong winds [3].

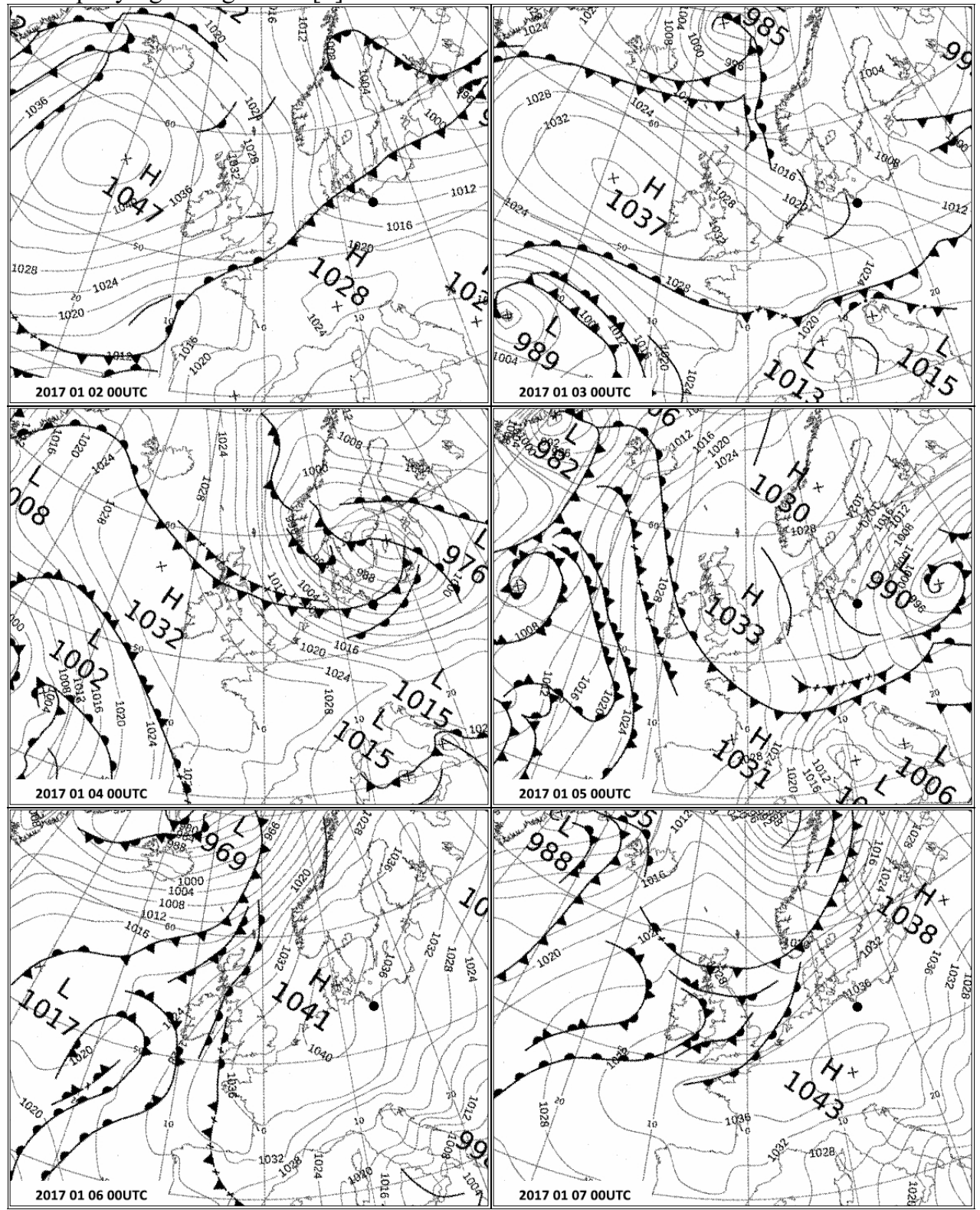

Fig. 1. Pressure field distribution on 02-07 January 2017 (dot indicates estuary section of the Oder River) [7]. 
January 2, 2017 00UTC weather situation in this region is causing by high pressure system with the center on the west of Ireland with a maximum pressure in the center $1047 \mathrm{hPa}$, and by low pressure $993 \mathrm{hPa}$ with the center south of Lake Onega in Russia. Lower Oder area is ahead of the advancing cold front. This causes the advection of air masses from the west sector, so the situation conducive to pour ocean waters to the Baltic Sea through the Danish Straits (Fig. 1.).

On 3. January the pressure in the center of high decreases to $1037 \mathrm{hPa}$, while the area occupied by it decreases assuming the stretched shape on the latitudinal axis WNW-ESE. Over Norwegian Sea low-pressure system with the pressure of $985 \mathrm{hPa}$ is marked clearly. Air circulation is still causing the occurrence of westerly winds in the relevant area.

January 4. - the low-pressure center is located in the area of central Baltic over Gotland. The minimum pressure at the center is $976 \mathrm{hPa}$. In conjunction with the passing of the next cold front the winds begin to change their direction from west to north-west. After 1PM warning levels are exceeded at gauges in Gryfino and Szczecin Most Długi (Long Bridge). After 1PM warning levels are exceeded at gages in Gryfino and Szczecin Most Długi (Long Bridge). Regional Water Management (Regionalny Zarząd Gospodarki Wodnej) in Szczecin in the Communication 1/2017 warns about the possibility of reaching or exceeding the state of great navigable water (WWŻ) on the gauges Szczecin Most Długi (Long Bridge), Gryfino Western Oder, Szczecin Podjuchy, Gryfino Eastern Oder and Widuchowa [9].

On 5th January low-pressure system moves away a little to the east, the pressure increases to the value $991 \mathrm{hPa}$, decreases the value of barometric gradient, while the winds take north direction. Away from south-west Europe a high pressure area is organising and high pressure is stretching from Spain $(1031 \mathrm{hPa})$ through the British Isles $(1033 \mathrm{hPa})$ and then to Scandinavia $(1030 \mathrm{hPa})$. Alarm conditions on certain sections of the estuary of the Oder and Vistula are exceeded (fig. 2.). After 5AM an alarm level is exceeded at the water gauge in Gryfino and after 7AM the same situation is at the gauge on the Most Długi (Long Bridge) in Szczecin.

On 6th January low-pressure system starts to disappear moving further east. The high pressure system is expanding and its center is located over the Jutland Peninsula (1041hPa). As a result, the winds diminish. After 6AM the water falls below an alarm level on gauge in Szczecin Most Długi (Long Bridge) and after 3PM at the water gauge in Gryfino.

On 7th January the center of High moves slightly south and the pressure system extends covering most of the Europe. The wind directions over the area of Lower Oder begins to be mainly from south-west sector.

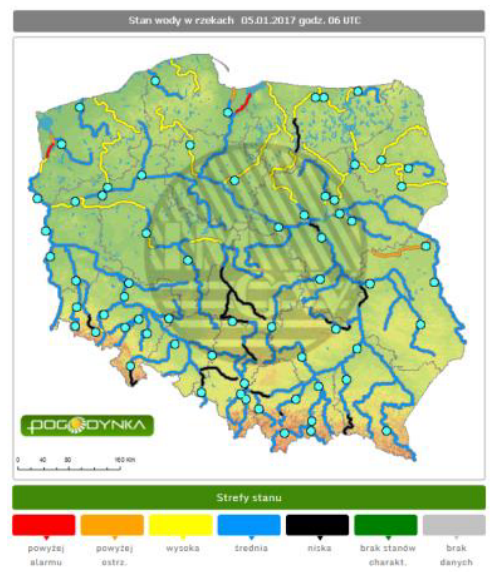

Fig. 2. Water levels in rivers on 5th January 2017, 0600UTC [08]. 


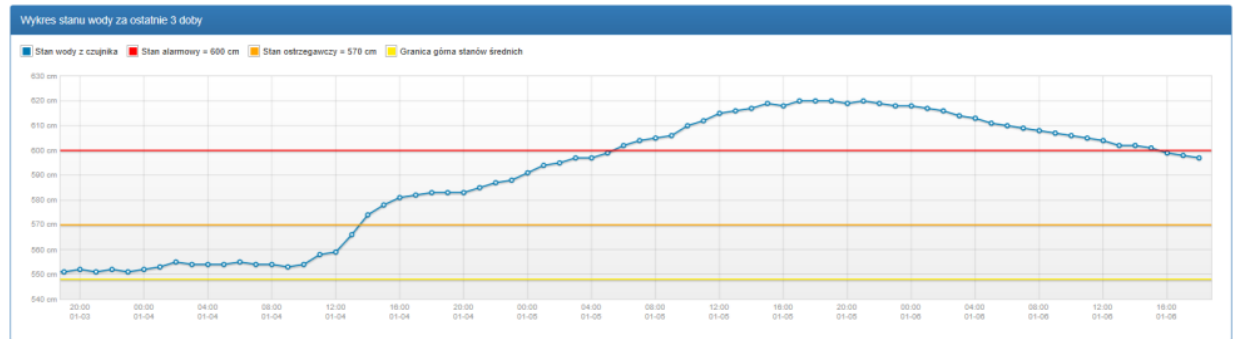

Fig. 3. Water level for last 3 days on water gauge in Gryfino, 6. January 2017, 06UTC [08].

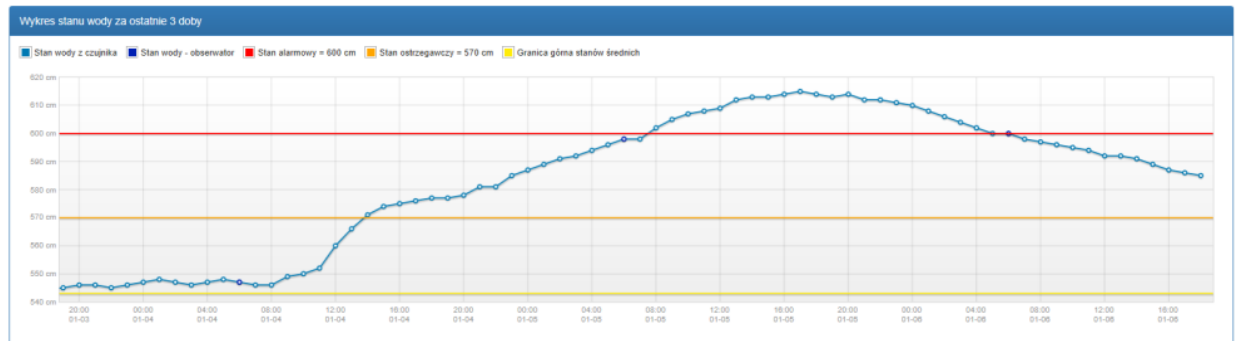

Fig. 4. Water level for last 3 days on water gauge in Szczecin Most Długi (Long Bridge), 6. January 2017, 06UTC [08].

Raising of the water level has marked clearly on 5. January, 2017 and the next day the situation began to return to normal (Fig. 3, 4). Hydrological situation in the morning on January 5. (06 UTC) is presented in Table 4. Warning levels were exceeded all the way from Świnoujście up to Gryfino. The highest overdraft of warning level was recorded in Świnoujście, at 0600UTC it was $62 \mathrm{~cm}$.In Trzebież warning level has been exceeded by $49 \mathrm{~cm}$, about $32 \mathrm{~cm}$ in Gryfino, in Szczecin Most Długi (Long Bridge) about 28cm, and in Szczecin Podjuchy about $27 \mathrm{~cm}$. Exceeding of the alarm level disposed as follows: Świnoujscie - $42 \mathrm{~cm}$, Trzebież - 29cm, Gryfino - 2cm. In Szczecin Most Długi (Long Bridge) and in Szczecin Podjuchy exceeding of the alarm level was not recorded. At the same time, in Szczecin wind speed of the magnitude $17 \mathrm{~m} / \mathrm{s}$ was recorded and in Świnoujście measured wind speed was $21 \mathrm{~m} / \mathrm{s}$.

Table 4. Hydrological situation on January 5th, 2017 at 0600 UTC on selected water gauges [8].

\begin{tabular}{|c|c|c|c|c|c|c|}
\hline $\begin{array}{c}\text { Gauge } \\
\text { position }\end{array}$ & $\begin{array}{c}\text { Water } \\
\text { level } \\
\mathbf{( c m )}\end{array}$ & $\begin{array}{c}\text { Level } \\
\text { change } \\
\mathbf{( c m / 2 4 h )}\end{array}$ & $\begin{array}{c}\text { Warning } \\
\text { level (cm) }\end{array}$ & $\begin{array}{c}\text { Alarm } \\
\text { level } \\
\mathbf{( c m})\end{array}$ & $\begin{array}{c}\text { Alarm } \\
\text { level } \\
\text { exceeding } \\
\mathbf{( c m})\end{array}$ & $\begin{array}{c}\text { Warning } \\
\text { level } \\
\text { exceeding } \\
\text { (cm) }\end{array}$ \\
\hline Świnoujście & 622 & 94 & 560 & 580 & 42 & 62 \\
\hline Trzebież & 589 & 49 & 540 & 560 & 29 & 49 \\
\hline $\begin{array}{c}\text { Szczecin Most } \\
\text { Długi }\end{array}$ & 598 & 51 & 570 & 600 & - & 28 \\
\hline $\begin{array}{c}\text { Szczecin } \\
\text { Podjuchy }\end{array}$ & 607 & 51 & 580 & 610 & - & 27 \\
\hline Gryfino & 602 & 47 & 570 & 600 & 2 & 32 \\
\hline
\end{tabular}

\section{Conclusions}

Several factors contribute to the occurrence of extreme sea levels on the Polish coast, leading consequently to the phenomenon of backwater and exceeding the alarm conditions 
in the estuary sections of rivers [5]. One of them is the pouring the southern Baltic by wind generated flow of water through the Danish Straits, and thus the higher state of the sea reached even before the surge [2]. The second is the effect of wind, which consists of direction towards the shore, its speed and duration. The third is a deformation of the water surface level caused by the movement of the low pressure system over the central or southern Baltic Sea, generating waves of great length - baric wave and fluctuations in the water level of a quasi-seiche nature [4].

The situation described above was therefore typical for this part of the coast region. It was not a particularly strong surge, $94 \mathrm{~cm}$ in Świnoujście, it was also not a particularly long - storm surges generated by lows typically persist through a period of 2 to 5 days. The weather situation, however, caused exceeding of the alarm levels on the river and temporarily preclude shipping on some of its sections.

The area of Lower Oder region is difficult to navigate. There are a number of restrictions imposed by the width of the shipping lane or clearance under bridges. Weather conditions affect the level of water in the river, which can interrupt or exclude shipping. Proper regulation of the river provides correct flow of the river. Navigational infrastructure does not act as regulatory and does not minimize the impact of backflow, which greatly affects the value of the vertical clearances under bridges, minimizing the possibility of transport. This shows the particular importance of current information relevant to navigation and weather conditions in Lower Oder area.

This research outcome has been achieved under the grant - Modelowanie ryzyka eksploatacji statku manewrującego na akwenie ograniczonym No 4/S/INM/15 financed from a subsidy of the Ministry of Science and Higher Education for statutory activities.

\section{References}

1. Rozporządzenie Rady Ministrów z dnia 07 maja 2002r. w sprawie klasyfikacji dróg wodnych (Council of Ministers of 07. May 2002 regulation on the classification of waterways)

2. I. Stanisławczyk, M. Sztobryn, Zmiany napetnienia Battyku jako wskaźnik oceanicznych wlewów powierzchniowych., XII Międzynarodowa Konferencja Naukowo-Techniczna - Rola Nawigacji w Zabezpieczeniu Działalności Ludzkiej na Morzu, Wydawnictwa AMW, Gdynia (2000)

3. M. Sztobryn i inni, Storm Surges in the Southern Baltic Sea (Western and Central Parts)., Berichte des Bundesamtes fur Seeschifffahrt und Hydrographie, Nr 39 (2005)

4. B. Wiśniewski, Oddzialywanie niżów barycznych na stany wód w estuarium Odry., (w) Geotechnika w warunkach oddziaływanie morza, Politechnika Szczecińska, Szczecin (2002)

5. B. Wiśniewski, T. Wolski, Katalogi wezbrań i obniżeń sztormowych poziomów morza oraz ekstremalne poziomy wód na polskim wybrzeżu., Akademia Morska, Szczecin (2009)

6. http://kgt.szczecin.rzgw.gov.pl

7. http://www.metoffice.gov.uk

8. http://www.pogodynka.pl

9. http://www.szczecin.rzgw.gov.pl 